\title{
Usaha Perjuangan Pahlawan Datuk Ibrahim Tan Malaka dazlam Mencapai Pembebasan Nasional Indonesia Tahun 1919-1949
}

\author{
Ade Fathul Anam Putra ${ }^{1)}$, Zuriatin $^{1)}$, Rosdiana ${ }^{1)^{*}}$ \\ ${ }^{1)}$ STKIP Taman Siswa Bima \\ *rosediana8885@gmail.com
}

\section{Artikel Info}

Tanggal Publikasi

2020-12-15

Kata Kunci

Usaha Perjuangan

Tan malaka

Pembebasan

Nasional

\begin{abstract}
Abstrak
Tujuan penelitian ini adalah (1) untuk mengetahui kondisi Nusantara pada masa pergerakan nasional, (2) untuk mengetahui bagaimana riwayat hidup Datuk Ibrahim Tan Malaka dan (3) untuk mengetahui usaha perjuangan pahlawan Datuk Ibrahim Tan Malaka dalam mencapai pembebasan nasional Indonesia tahun 1919-1949. Jenis penelitian yang di gunakan oleh peneliti adalah penelitian kepustakaan (Library research), penelitian ini menggunakan langkah-langkah yaitu (1) Heuristk, proses pengumpulan data (2) Kritik sumber, proses penyeleksian data (3) Interprestasi, penafsiran data (4) Historiografi, penulisan sejarah. Dalam penulisan skripsi ini. Pendekatan yang di gunakan adalah pendekatan sosial dan politik. Hasil penelitian ini menyimpulkan bahwa Perjuangan bangsa Indonesia menghadapi penjajah dipicu oleh harga diri sebagai bangsa yang ingin merdeka di tanah airnya sendiri tanpa tekanan penjajah. Munculnya politik etis memberikan dampak positif bagi rakyat Indonesia, kebijakan politik etis memberikan peluang mudahnya akses pendidikan bagi kaum pribumi yang membawa dampak lahirnya kaum terdidik terpelajar yang menjadi pelopor kebangkitan bangsa termasuk di antaranya Tan Malaka. watak revolusioner Tan Malaka tumbuh dan berkemnbang ketika ia menempuh pendidikan di belanda, melalui pengalaman dan buku-buku yang ia baca selama di Belanda. Usaha perjuangannya dimulai dari tahun 1919 mulai dari mendirikan sekolah rakyat di Semarang, menjadi ketua PKI menggantikan Samaun, mendirikan Partai Republik Indonesia PARI di Bangkok, menggagas terbentuknya organisasi pesatuan perjungan, dan pada tanggal 7 November 1948 Tan Malaka mendirikan partai yang bersifat revolusioner untuk mempertahankan kemerdekaan Indonesia yang bernama partai Murba. Cita-cita menuju kemerdekaan $100 \%$ itu yang mengharuskan Tan Malaka, tidak hanya melihat kemerdekaan hanya sekedar kemerdekaan politik, namun kemerdekaan Indonesia menyeluruh sifatnya, mulai dari kemerdekaan ekonomi, politik, sosial dan budaya.
\end{abstract}

\section{Pendahuluan}

Pertama kali masuknya bangsa Eropa di Indonesia ditandai dengan kedatangan bangsa Portugis yang disusul oleh Spanyol pada Abad ke 16 Masehi kemudian diteruskan dengan kedatangan bangsa Belanda yang merupakan negara paling lama menjajah Indonesia selama 350 tahun, dan terakhir Jepang selama 3,5 tahun. Awalnya tujuan kedatangan bangsa Eropa tersebut hanya sekedar berdagang dan mencari rempah-rempah. Namun tujuan tersebut berubah menjadi keinginan menguasai dan memonopoli seluruh perdagangan yang ada di Nusantara. Selanjutnya mereka berhasil melakukan kolonialisme dan imperialisme, Dampak yang ditimbulkan dari penjajahan ini sangat besar pengaruhnya terhadap seluruh aspek kehidupan terutama bagi negara yang dikuasai. Salah satu aspek kehidupan yang memperoleh pengaruh cukup besar yaitu aspek kebudayaan (Djoko Soekiman, 2000: $1-5)$.

Pada aspek sosial sistem tanam paksa menjadi salah satu permasalahan yang di hadapi masyarakat Indonesia pada saat itu. Sistem tanam paksa yang berlangsung selama 40 tahun (1830-1870) telah 
mendatangkan keuntungan yang begitu besar bagi pemerintahan Kerajaan Belanda, sebaliknya bagi rakyat Indonesia sistem tanam paksa tersebut mengakibatkan rakyat semakin tertindas dan menderita, kemiskinan dan kelaparan terjadi di mana-mana bahkan tidak sedikit rakyat yang meninggal dunia akibat penderitaan dan kelaparan tersebut (Junaidin Al Anshori, 2008: 75-76).

Penderitaan rakyat Indonesia akibat tanam paksa menimbulkan berbagai reaksi, kecaman keras dan perlawanan, baik dari bangsa Indonesia maupun dari bangsa Belanda itu sendiri. Salah satunya datang dari C. Th Van Deventer pada akhir abad ke-19, mengkritik keadaan itu melalui salah satu karangannya yang berjudul Utang Budi. C. Th Van Deventer menyatakan bahwa "kemakmuran Belanda diperoleh berkat kerja dan jasa orang Indonesia”. Oleh sebab itu bangsa Belanda sebagai bangsa yang maju dan bermoral harus membayar utang budi kepada bangsa Indonesia. Caranya adalah dengan menjalankan Politik Balas Budi atau dikenal dengan sebutan Politik Etis.

Politik Etis yang diusulkan oleh Van Deventer berisi tentang perbaikan-perbaikan dalam bidang irigasi (pengairan), transmigrasi (perpindahan), dan edukasi (pendidikan). Akan tetapi pelaksanaannya tidak terlepas darikepentingan pemerintah Hindia Belanda. Politik Etis sebenarnya merupakan bentuk penjajahan kebudayaan yang halus. Program edukasi itu sendiri sebenarnya merupakan pelaksanaan dari Politik Asosiasi yang berarti penggantian kebudayaan asli tanah jajahan dengan kebudayaan penjajah. Walaupun menyimpang dari tujuan semula, beberapa pelaksanaan dari Politik Etis telah membawa pengaruh yang baik Misalnya, dengan didirikannya sekolah-sekolah untuk golongan pribumi. Tujuannya adalah untuk memperoleh tenaga baru pegawai rendah yang bersedia digaji lebih murah dari pada tenaga bangsa-bangsa Belanda.

Dengan adanya kebijakan politik ini terbukalah kesempatan yang makin luas dikalangan pribumi untuk memperoleh pendidikan modern ala Belanda. Pendidikan ini juga untuk memenuhi kebutuhan atas tenaga-tenaga terdidik untuk birokrasi. Dari sinilah munculnya beberapa intelektual muda yang bersentuhan dengan pemikiran barat, termasuk tentang Nasionalisme (Alfian 1986: 164).

Semakin meningkatnya jumlah penduduk pribumi yang bersekolah telah menghasilkan kaum cerdik pandai dikalangan penduduk pribumi. Kaum cerdik pandai inilah yang mempelopori kesadaran kebangsaan, yaitu suatu kesadaran tentang perlunya persatuan dan kesatuan bangsa. Peristiwa timbulnya kesadaran berbangsa disebut Kebangkitan Nasional Indonesia. Kaum cerdik pandai ini pula yang mempelopori dan memimpin pergerakan Nasional pada awal abad ke-20.

Dari beberapa tokoh yang dihasilkan melalui politik Etis terdapat satu tokoh yang dilupakan dalam kanca sejarah Indonesia adalah Tan Malaka. Beliau memiliki peran yang luar biasa dalam mencapai pembebasan nasional Indonesia. Perjalana pendidkaan bagi Tan Malaka di mulai dari sekolah Desa di Suliki sampai kelas dua, kemudian pindah ke Koto VII Tanjung Ampulu mengikuti ayahnya yang pindah kesana. Terakhir beliau pindah ke Sariak Alahan dan menamatkan sekolah Gubernemen kelas lima, kemudian melanjutkan kesekolah raja atau Kweekschool di Fort de kock, di Bukit Tinggi. Masa studi di Kweekschool Fort de kock dapat dikatakan sebagai rantau pertama dari Tan Malaka. Di sekolah ini beliau banyak terbuka pemikirannya terhadap cara berpikir Barat. Lalu Pada tahun 1913, Tan Malaka pergi ke Belanda untuk melanjutkan studinya di Rijks Kweekscool, Harleem. Masa studi beliau disekolah ini biasa disebut sebagai perkenalan pada dunia luar. Berhasil beliaumenempuh studi di Rijks kweekschool tidak terlepas dari peran G. Horensma yang berhasil meyakinkan Direktur Van Der Ley bahwa Tan Malaka adalah murid yang pandai.

Di sekolah Rijks Kweekscool Tan Malaka mampu untuk mengatasi masalah pelajaran walaupun terkadang terkendala oleh bahasa. Selain itu, Tan Malaka juga dikenal sebagai siswa yang mudah bergaul dengan guru ataupun dengan siswa lainnya. Dia aktif dalam klub sepak bola dan juga klub orkestra di sekolah. Selama masa studi di Belanda Tan Malaka juga mulai berkenalan dengan karyakarya penulis-penulis Eropa seperti Nietzche, Th. C. Arlyle, Karl Marx, Engels, Karl Kautsky yang 
membuatnya berada dalam semangat dan paham revolusioner. Perkenalannya dengan bacaan-bacaan itu mempunyai dampak yang tidak kecil dalam diri Tan Malaka, terutama dalam cara berfikirnya.

Pengaruh Pendidikan dalam pemikiran Tan Malaka tentunya memegang peranan yang sangat penting, terutama dalam mempengaruhi pemikiran serta garis politiknya. Beberapa karya yang di hasilkannya merupakan representasi dari hasil perjumpaannya dengan dunia pendidikan Barat. Tan Malaka menuangkan gagasan-gagasannya kedalam sekitar 27 buku, brosur dan juga ratusan artikel. Karya-karya Tan Malaka meliputi bidang kenegaraan, politik, ekonomi, sosial, budaya dan militer (Rambe, 2003: 90).

Karya-karya Tan Malaka itu antara lain, Naar de Republik, Massa Aksi, Madilog, Semangat Muda dan lain-lain. Dari tulisan-tulisan itulah kita dapat mengenal dan menyelami gagasan-gagasan Tan Malaka yang selalu berlandaskan pada cara berfikir ilmiah, mengutamakan ke Indonesiaan, konsekuen, dan juga konsisten. Penerimaannya terhadap pemikiran Barat bukan berarti menyerahkan segala sesuatu pada hukum Barat tetapi lebih sebagai upaya untuk mempelajari nilai-nilai budaya Barat. Karena untuk dapat mengalahkan musuh tentulah harus di pahami kekuatan dan kekurangan dari musuh tersebut. Dalam beberapa kesempatan ataupun dalam tulisannya, Tan Malaka banyak sekali mempergunakan referensi atau rujukan dari karya- karya yang telah disebutkan diatas. Sebagai contoh dalam tulisannya yaitu Madilog. Madilog lahir dari sintesis pertentangan pemikiran diantara dua kubu aliran filsafat, yaitu Hegel dan Marx-Engels. Hegel dengan filsafat dialektika (Tesis Antitesis- Sintesis) dengan kebenaran yang menyeluruh hanya dapat tercapai melalui perkembangan dinamis, dari taraf gerakan yang paling rendah sampai paling tinggi (Hidayat, 2010: 61)

Madilog merupakan sebuah panduan cara berfikir baru, sebuah warisan dari pusaka intelektual barat Marxis-Leninis yang dinilai rasional. Cara berfikir ini nantinya diharapkan akan menggantikan cara berfikir ketimuran khususnya Indonesia yang dianggapnya masih dikuasai oleh budaya Mistik dan Idealistik. Selain itu, Madilog adalah representasi logis dan filosofis pemikiran Tan Malaka dan merefleksikan ke-Indonesiaan. Dalam melihat fenomena yang terjadi terhadap bangsa Indonesia, menurutnya tidak hanya merunut pada kultur penyebabnyamelainkan sekaligus menunjuk bagaimana bisa keluar dari penjajahan.

Tan Malaka merupakan tokoh kemerdekaan yang terkenal dengan pemikiran dan gagasan yang radikal dan beranggapan bahwa revolusi menjadi cara terakhir ketika mogok dan boikot yang dilakukan rakyat proletar tidak diperhatikan. Revolusi yang dilakukan bukan semata-mata ingin menggulingkan pemerintahan ataupun anarkisme, melainkan usaha yang dilakukan rakyat untuk mempertahankan kedaulatan dan melepaskan diri dari pengaruh-pengaruh yang menganggu kemerdekaan. Pemikiran yang telah dihasilkan oleh Tan Malaka telah memberikan bukti nyata, bahwa pemikirannya membawa dampak yang signifikan. Dampak dari pemikirannya menjalar kepada para pemuda dan para golongan tua yang revolusioner, meskipun mengalami pertentangan (Alfian, 1986: 150).

Berdirinya Persatuan Perjuangan dan Partai Murba, bahkan peristiwaperistiwa yang terjadi di sekitar masa revolusi, merupakan pengaruh dari gagasan-gagasan dan pemikiran-pemikiran yang telah dilahirkan oleh Tan Malaka. Jika kita mengamati hidup dan perjuangan Tan Malaka, jelas sekali bahwa sejak awal dia hidup untuk merevolusionerkan kaum murba, agar menjadi kekuatan massa dalam merebut kemerdekaan seutuhnya. Aksi massa yang dilakukan oleh segenap rakyat Murba Indonesia dengan perjuangan revolusi dapat mengembalikan kemerdekaan Indonesia yang seutuhnya (Alfian, 1986: 150).

\section{Metode Penelitian}

Jenis penelitian ini adalah penelitian historis. Metode yang digunakan dalam penelitian ini menggunakan metode penelitian sejarah. Metode sejarah adalah proses menguji, menganalisis serta 
perbandingan secara kritis rekaman dan peninggalan masa lampau sedangkan rekonstruksi dengan menempuh proses historiografi atau penulisan sejarah (Gottschalk, 1985:32).

Metode sejarah terdiri dari empat langkah, yaitu heuristic, kritik sumber, interpretasi dan historiografi. Tahap pertama heuristik adalah kegiatan untuk mencari dan menemukan jejak sejarah. Tahap kedua adalah kritik sumber. Kritik sumber yaitu kegiatan meneliti untuk menentukan validitas dan reliabilitas suatu sumber sejarah yang berhasil dikumpulkan. Kritik terbagi menjadi 2 yaitu kritik ekstern dan kritik intern. Pada kritik ekstern penulis melakukan kritik siapa yang membawa berita dan menulis sumber mengenai buku yang dijadikan bahan dalam penulisan ini. Kritik intern penulis melakukan kritik terhadap suatu sumber dengan membandingkan isi data atau isi buku sejarah yang telah ditulis pengarang tersebut. Tahap ketiga adalah interpretasi atau penafsiran. Interpretasi terdiri dari analisis dan sintesis. Analisis adalah menguaraikan data-data diperoleh, sedangkan sintesis berarti menyatukan datadata sehingga ditemukan fakta sejarah (Abdurahman, 2007: 68). Fakta disusun secara kronologis dan membentuk fakta rasional dan faktual berdasarkan pada aspek pembahasan. Tahap keempat adalah historiografi atau penyajian. Historiografi yaitu penyajian hasil penelitian sejarah dengan melewati tahaptahap di atas dalam bentuk karya sejarah (Hugiono, dkk, 1992: 26). Dalam tahap ini penulis menyajikan dalam bentuk jurnal ilmiah.

\section{Hasil dan Pembahasan}

\subsection{Kondisi Nusantara Pada Masa Pergerakan Nasional}

\section{Kondisi Pendidikan Nusantara Pada Masa Pergerakan Nasional}

Rasa kebangsaan terbentuk sejak kebangkitan nasional pada tahun 1908. Perjuangan yang dilakukan bangsa Indonesia menghadapi penjajah dipicu oleh harga diri sebagai bangsa yang ingin merdeka di tanah airnya sendiri tanpa tekanan penjajah. Hal ini ditunjang dengan munculnya pendidikan. Kebutuhan pendidikan telah didasari sebagai kebutuhan yang tidak bisa ditunda dan diabaikan lagi, kesadaran ini semakin hari semakin meluas di Indonesia. Pendidikan pula yang akhirnya melahirkan golongan terpelajar yang mampu membuka kesadaran bahwa penguasaan ilmu pengetahuan merupakan bekal untuk menghadapi bangsa Barat menuju kemerdekaan (Yudi Setianto, 2016: 54).

Banyaknya penduduk pribumi yang bersekolah telah menghasilkan kaum cerdik pandai dikalangan penduduk pribumi diantaranya Dr. Soetomo, Ki Hajar Dewantara, Wahid Hasym, Samanhudi, dan Abdul Muis. Kaum cerdik pandai inilah mempelopori kesadaran kebangsaan, yaitu suatu kesadaran tentang perlunya persatuan dan kesatuan bangsa. Peristiwa timbulnya kesadaran berbangsa disebut Kebangkitan nasional Indonesia. Kaum cerdik pandai ini pula yang mempelopori dan memimpin pergerakan nasional pada awal abad ke-20. Dari beberapa tokoh yang dihasilkan melalui politik etis terdapat satu tokoh yang dilupakan dalam kanca sejarah Indonesia padahal perannya cukup luar biasa dalam mencapai pembebasan nasional Indonesia beliau adalah Tan Malaka. Tan Malaka lahir pada abad ke-19, pada saat politik etis Belanda mulai berlaku di Indonesia. Adanya kebijakan politik ini terbukalah kesempatan yang makin luas dikalangan pribumi untuk memperoleh pendidikan modern ala Belanda. Pendidikan ini juga untuk memenuhi kebutuhan atas tenaga-tenaga terdidik untuk birokrasi. Dari sinilah munculnya beberapa intelektual muda bersentuhan dengan pemikiran Barat, termasuk tentang nasionalisme. Mungkin setiap masyarakat dalam pertemuan dengan dunia luar, seperti Barat akan terpaksa membuka dirinya menerima kemungkinan lahirnya orang-orang yang berani berfikir dinamis dan kritik sebagai akibat langsung dari pertemuan kedua kebudayaan itu (Alfian, 1986:164).

\section{Kondisi Politik Nusantara Pada Masa Pergerakan Nasional}


Munculnya Pergerakan nasional tak terlepas dari lahirnya beberapa organisasi yang memiliki watak perjuangan maju seperti Budi Utomo, kemudian Serikat Dagang Islam, Serikat Islam, Indische Partij, Perhimpunan Indonesia, Partai Komunis Indonesia, Partai Nasional Indonesia, Partai Indonesia Raya (PARINDA), dan Gabungan Politik Indonesia (GAPI). Selain organisasi yang bercorak politik, berkembang juga organisasi masa non politik yang bergerak di bidang sosial, pendidikan, dan budaya. Organisasi masa ini ada yang bercorak agama, nasional, dan daerah (Junaedi Al Anshori, 2010: 94).

Partai Komunis Indonesia PKI, dan Paratai Republik Indonesia PARI merupakan alat perjuangan yang pernah digunakan oleh Tan Malaka dalam melakukan perjuangan pembebasan nasional Indonesia, tetapi bukan partai yang awet. Dia merantau selama 20 tahun, dari Padang Gadang (Suliki), Bukittinggi, Batavia, Semarang, Yogyakarta, Bandung, Kediri, Surabaya, Amsterdam, Berlin, Moskow, Shanghai, Canton, Manila, Saigon, Bangkok, Hong Kong, Singapura, Rangoon, sampai Penang. Meskipun sempat memimpin Partai Komunis Indonesia pada tahun 1921, Tan Malaka justru menolak pemberontakan PKI pada 1926/1927. Dia juga sama sekali tidak terlibat dalam peristiwa Madiun 1948. Partai Murba yang didirikanya, dalam berbagai hal bertentangan dengan PKI. Tan Malaka mendirikan Partai Republik Indonesia PARI di Bangkok pada 1 Juni 1927. Walaupun bukan partai masa, organisasi ini hidup selama sepuluh tahun pada saat partai-partai nasionalis di tanah air lahir dan mati. PARI dianggap berbahaya oleh intel Belanda, dan aktivisnya di buruh (Taufik Susilo, 2016: 94).

Tan Malaka dan ke dua kawannya di Bangkok, sampailah berita pada mereka bahwa orang-orang Nasionalis telah mendirikan perserikatan, Partai Nasional Indonesia PNI, pada 4 Juli 1927, PNI dipimpin oleh Soekarno, dan mencita-citakan kemerdekaan Indonesia, untuk itu, partai ingin memperkuat kesadaran nasional atas dasar prinsip non-kooperasi dengan pemerintah. Tan Malaka sangat gembira mendengar gagasan tersebut. Mengenai hal itu, Tan menulis sebua brosul berjudul Pari dan Kaum Intelektual Indonesia. Dalam brosul itu beliau mengusulkan untuk berjuang bersama mencapai kemerdekaan dibidang politik, sosial dan ekonomi. Kaum cendekiawan, katanya, harus memegang pimpinan organisasi masa buruh, petani, pemuda, dan menempahnya menjadi organisasi yang berdisiplin dan bersatu (Taufik Susilo, 2016: 94).

Pada umumnya pemikiran pemikiran dan perjuangan Tan Malaka terpusat pada satu tujuan untuk kemerdekaan bangsanya dan sekaligus merombak secara total dan drastis dalam bidang politik, ekonomi, sosial, dan budaya. Dalam kaitannya dengan kemerdekaan Indonesia, Tan Malaka menganggap bahwa dengan jalan Revolusilah Indonesia dapat melepaskan diri dari lingkungan kelas dan penjajahan. Tan Malaka menganggap bahwa Revolusi Indonesia mempunyai dua tombak yaitu, mengusir Kapitalisme- Imperialisme dan mengikis sisa-sisa Feodalisme.

\section{Kondisi Ekonomi Nusantara Pada Masa Pergerakan Nasional}

Pemerintah Kolonial membentuk suatu komite untuk menyelidiki keadaan ekonomi rakyat jajahan. Dasar awal politik etis adalah usaha untuk membalas budi bangsa Indonesia, namun pada kenyataan hal tersebut hanya semata-mata rencana yang tidak terlaksana secarah utuh. Politik etis hanya memberikan harapan untuk meningkatkan taraf hidup lebih baik. Eksploitasi yang dilakukan oleh penjajah kolonial menimbulkan reaksi-reaksi dikalangan golongan terpelajar, penjajah melakukan tindakan-tindakan ekonomi hanya untuk melindungi kepentingan kolonial di bidang ekonomi (Kartodirjo, 1999: 233).

Kepentingan penjajah diutamakan dari pada kepentingan rakyat jajahan. Kepentingan tersebut menyebabkan kondisi rakyat jajahan yang terbelakang, akibat pelaksanaan eksploitasi dan diskriminasi oleh pemerintah kolonial Belanda. Keadaan dalam negeri Indonesia telah pemperlihatkan perkembangan ekonomi yang meningkat. Diskriminasi dilakukan penjajah Belanda menimbulkan usaha-usah kearah emansipasi ekonomi, diskriminasi dan eksploitasi dikalangan rakyat menimbulkan 
rasa benci dikalangan golongan terpelajar. Mohammad Hatta berusaha meningkatkan kemampuan ekonomi masyarakat, Hatta beranggapan bahwa penjajah ingin menguasai seluruh hasil negeri jajahan.Hatta bersama dengan golongan terpelajar melakukan reaksi sebagai wujud dari kekecewaan terhadap eksploitasi yang dilakukan oleh pemerintah kolonial Belanda secara besar- besaran ditanah jajahan Indonesia (Sumardi, Dkk, 2017: 289).

Pertentangan ekonomi tersebut menyebabkan keadaan pada pergerakan nasional masih tetap terbelakang. Kondisi ekonomi menjadi terbelakang karena sistem produksi pada masa pergerakan nasional masih menggunakan produksi lama yang tidak mampu menghadapi kapitalis kolonial yang membunyai organisasi dan tekhnologi modern. Keadaan yang terus seperti ini, menghalangi usaha perekonomian bangsa Indonesia menimbulkan suatu sikap solidaritas yang mengarah pada usaha emansipasi ekonomi. Pada masa pergerakan nasional kengiatan perekonomian masyarakat Indonesia yang masih pedagang, maka mewujudkan solidaritas dengan bentuk reaksi diucapkan pada pedagang asing. Pihak pergerakan nasional Indonesia, seperti Sarekat Islam misalnya bertujuan untuk meningkatkan kehidupan ekonomi rakyat dengan memajukan perdagangan dan melindungi kebutuhan-kebutuhan materialnya.

Usaha Sarekat Islam yang bersifat ekonomi membawa pengaruh pada organisasi lain untuk membantu perekonomian bangsa Indonesia, yaitu Budi Utomo, Pasundan, Perkumpulan Bupati. Kemudian segera menyusul ide kemajuan beserta cita-cita untuk meningkatkan taraf kehidupan bangsa Indonesia. Ide-ide muncul tersebut akan melandasi pergerakan organisasi-organisasi yang tumbuh dan berkembang pada masa itu. Bahkan masing-masing organisasi memiliki dasar dan idiologi yang dapat memperkuat kedudukan maupun perjuangannya (Aydha, Kurniawati, 2014: 3).

\section{Kondisi Sosial Budaya Nusantara Pada Masa Pergerakan Nasional}

Kondisi sosial bangsa Indonesia pada awal abad ke-20 juga menghadapi praktek diskriminasi dari kolonial Belanda. Diskriminasi itu berdasarkan ras, golongan dalam masyarakat dan suku bangsa. Dalam diskriminasi ras, warna kulit seseorang menentukan statusnya, bahkan di adakan pula perbedaan gaji antara serdadu pribumi yang berlainan suku, dalam hal ini suku Jawa yang paling disayangi pemerintah kolonial karna dianggap penurut. Belanda juga melakukan pembagian kelas sosial dengan keadaan seperti ini, mengakibatkan kondisi sosial masyarakat Indonesia kurang lancar. Kurang hubungan antara masyarakat dan penjajah, hal ini berakibat di daerah terjadi ketimpangan sosial.

Diskriminasi berdasarkan ras hampir terjadi diseluruh sendi kehidupan sosial. Pembatasanpembatasan jabatan yang tajam ditentukan atas dasar rasial dan mobilitasnya ke atas ditentukan batasan-batasan sampai pada tingkat tertentu. Diskriminasi ras ini ditandai dengan kaum bumi putra yang berkutat pada jabatan-jabatan rendah dan pada lapisan atas yang tipis terdiri atas golongan Eropa, dan perbedaan antara status ekonomi golongan kecil penduduk kulit putih dan masyarakat bumiputra dibagian yang paling bawah. Selain itu adanya pembatasan-pembatasan pergaulan sosial antara ras, dan adanya pemisahan fisik yang mencolok membuat diskriminasi ditengah masyarakat. Bentuk lahiriah wilayah Indonesia pada saat ini masih menjadi bukti adanya pemisahan pada zaman kolonial itu (Aydha, Kurniawati, 2014: 5-6).

Sementara itu kondisi budaya masyarakat Indonesia terutama masyarakat Jawa sudah meniru budaya Barat yang diperkenalkan oleh masyarakat Barat, seperti berjudi dan meminum-minuman keras, yang merupakan budaya yang bertentangan dengan ajaran Islam. Seiring dengan perkembangan masyarakat kolonial Belanda di Indonesia maka di bangunlah sarana seperti rumah tinggal, tokoh, tempat rekreasi, sekolah, rumah sakit, hotel, bank, penjara dan lain-lain.Selain tinggal di Loji kecil orang-orang Belanda mulai menyebar pada kawasan lain (Kuntowijoyo, 2004: 52). 
3.2 Usaha Perjuangan Pahlawan Datuk Ibrahim Tan Malaka Dalam Mencapai Pembebasan Nasional Indonesia

\section{Usaha Perjuangan Pahlawan Datuk Ibrahim Tan Malaka pada Tahun 1919-1945}

Pada tahun 1919, Tan Malaka kembali ke Indonesia dan bekerja sebagai pengawas sekolah untuk anak-anak kuli pada Maskapai Senembah Deli pada bulan Desember 1919-Juni 1921. Di Deli, beliau melihat buruh-buruh diperkebunan itu hidup tidak layak, dan menganggap betapa kejamnya sistem kapitalis, sehingga Tan Malaka menyebutnya sebagai "tanah emas", surga bagi kaum kapitalis tapi tanah keringat air mata maut, neraka, buat kaum proletar.

Pada tahun 1921-1922 merupakan permulaan nyata karir politik Tan Malaka karena dia mendirikan sekolah rakyat di Semarang. Keadaan waktu itu tidak memungkinkan beliau membatasi kegiatan hanya dalam bidang pendidikan saja, maka beliau juga terjun dalam gerakan buruh dan kegiatan politik. Pertama, dia terpilih menjadi wakil ketua serikat pegawai pelican Hindia (SPPH) tambang minyak Cepu dengan Samaun sebagai pendiri dan ketua. Kemudian beliau juga terpilih sebagai ketua merangkap bendahara Sarekat Pegawai Percetakan.

Dalam konggers Kominter IV tahun 1922 yang diadakan di Moskow Tan Malaka hadir mewakili Indonesia. Disana beliau mendapat sorotan tajam karena menentang sikap permusuhan komintern terhadap Pan-Islamisme yang di anggap sebagai kekuatan borjuis yang tidak dapat dipercaya. Tan Malaka menekankan potensi Revolusioner Islam, diwilayah-wilayah jajahan dan pentingnya kerja sama dengan mereka. Di Indonesia, sejak awal penjajah Belanda sampai akhir kebangkitan kesadaran nasionalisme, pemberontakan melawan penjajah selalu dilakukan oleh pontensi Islam, antara lain SI sebab, kebanyakan orang Islam adalah petani dan buruh miskin tertindas yang menginginkan kebebasan nasional dari cengkraman Kolonial.

Meskipun ada pertentangan seperti itu Tan Malaka tetap diangkat menjadi wakil komintern untuk Asia Tenggara pada pertengahan 1923, kemudia beliau berangkat ke Cina dan mendirikan markas besar di Katon. Di tempat itu dia bertermu dan berkenalan dengan Sun Yat Sen serta sejumlah pemimpin Cina lainnya. Asia Tenggara yang menjadi daerah tanggung jawabnya meliputi Burma, Siam, Annam, Filipina, Malaysia dan Indonesia (Susilo, Taufik, 2008: 158).

Pada bulan Oktober 1925, pemimpin PKI waktu itu, Sardjono, Alimin dan Muso mengadakan rapat gelap dicandi prambanan, Yogyakarta. Mereka memutuskan pemberontakan melawan penindasan dan kesewenang-wenangan pemerintah kolonial. Walaupun keputusan itu tidak disetujui oleh Tan Malaka sebagai pemimpin tertinggi komintern Asia Tenggara, sebab menurut perhitungan perbandingan kekuatan dan keadaan, mengadakan pemberontakan waktu itu sama saja bunuh diri bagi PKI, akhirnya pemberontakan PKI meletus juga di Jawa Barat Pada bulan November 1926 dan di Sumatra Barat Januari 1927. Namun yang terjadi hanyalah gejolak kerusuhan kecil ditingkatan lokal yang mudah dipadamkan dan ditindas oleh pemerintah Hindia Belanda.

Melihat kenyataan seperti itu, Tan Malaka melepaskan dan memisakan diri dari PKI, dan hubungannya dengan komintern pun merenggang, bersama temanya Subakat, Djamaludin Tamin, dan Budi Sucitro, yang sehaluan dan sejalan. Tan Malaka akhirnya menempuh jalur sendiri, bersikap, dan bertindak mandiri. Pada April 1925, Tan Malaka menulis buku Menuju Republik Indonesia. Buku aslinya ditulis dalam bahasa belanda karena memang di tunjukan pada kaum pelajar Indonesia yang akan menjadi calon pemimpin politik nasional masa yang akan datang, baik yang ada ditanah air maupun yang ada di negeri Belanda.

Pada tahun 1927, bersama Subakat dan Djalaludin Tamin, Tan Malaka memproklamirkan pendirian Partai Republik Indonesia PARI di Bangkok. Partai ini bergerak dibawah tanah sebagai sarana perjuangan RI. Untuk mencapai cita-cita itu maka gabungan daerah mempunyai kewajiban untuk menyelesaikan perjuangan proletaris dalam daerahnya masing-masing. PARI sendiri telah lama 
menyusun program perjuangannya yang di arahkan pada usaha membasmi dan membinasakan imprealisme dan kapitalisme serta menyusun masyarakat proletaris dalam benua Asia. Tan Malaka sebagai pencipta dari pada ideologi PARI rupa-rupanya memusatkan segala tenaga dan jiwanya kepada perjuangan kemerdekaan Republik Indonesia. Maka dapat di pastikan, bahwa Indonesia yang hendak di jadikan pelopor dan pemimpin dari pada perjuangan membangun proletaris- proletaris Asia (Sudijono, Djojoprajitno, 2010: 125).

PARI berhasil memasukan jaringannya hampir keseluruh Indonesia dan dapat bertahan selama 10 tahun. Walaupun pemimpin-pemimpinya banyak di tangkap dan masuk penjara atau di hukum mati. Tan malaka sendiri terisolasi Cina-Jepang dipedalaman negeri tersebut. ketika beliau dalam keadaan sakit dan desanya diserang, beliau melarikan diri menyusuri negeri-negeri Asia Tenggara dan terdesak oleh tentara Jepang. Lalu beliau masuk ke Malaysia, Singgapura dan pada akhirnya sampai ke Medan. Dengan menyusuri Sumatra ia sampai ke Jakarta (Alfian, 1992: 171).

Kedudukan Tan Malaka yang kuat di gunakan untuk mengumpulkan pemuda disekitarnya dengan tujuan lebih dari sekedar memperbaiki nasib kaum romusa. Bagi Tan Malaka, para pemuda yang berasal dari berbagai daerah tersebut dapat mengatasi kuatnya primordial kedaerahan dan mempunyai rasa nasionalisme yang kuat, sebab masih dalam tekanan Jepang yang makin terdesak.

Jepang menolak pembentukan serikat pekerja romusa, maka Tan Malaka tidak kehabisan akal, beliau melakukan pengorganisiran diri bagi kaum buruh dipertambangan bayah dengan membentuk kelompok olah raga serta kelompok tonil (dram), upayah inipun berhasil. Keberhasilannya dalam menggalang romusa, Tan Malaka di tunjuk untuk memimpin kantor urusan prajurit pekerja KUPP setelah sebelumnya ia diangkat sebagai pengganti kepada badan pembantu keluarga peta BPP. Pada Juni 1945, Tan Malaka mendapat undangan dari BPP Rangkasbitung untuk membicarakan perkembangan dikalangan pemuda sehubungan dengan kemerdekaan. Pertemuan dari Rangkasbitung itu untuk menunjuk wakil dari Banten. Akhirnya pada pertemuan itu Tan Malak di tunjuk sebagai wakil dari Banten.

Sebagai wakil Banten untuk mengikuti kongres pemuda, yang di persiapkan sebagai menagih janji kemerdekaan yang hendak di berikan Jepang untuk Indonesia, Tan Malaka menolak jika kongges pemudamasih ada campur tangan Jepang. Kemerdekaan harus di ambil oleh tangan sendiri tanpa campur tangan dari jepang. Pada pertemuan kedua, Tan Malaka tidak ambil bagian karena ada urusan di Bayah, dimana pada pertemuan itu beliau merasa sangat ketinggalan dan tidak ikut melahirkan Republik. Pada tanggal 17 Agustus 1945 terdengar kabar bahwa para pemuda yang dikoordinir oleh Sukarni, kemudian hari pemuda ini menjadi pengikut Tan Malaka. Menculik Soekarno-Hatta untuk segera memproklamirkan kemerdekaan Indonesia. Kekuatan Jepang waktu itu lumpuh. Mereka menyerah tanpah syarat pada sekutu pada tanggal 14 Agustus 1945. Sehingga kesempatan tersebut diambil oleh para pemuda untuk segera memaklumatkan proklamasi kemerdekaan tampa menunggu pemberian Jepang (Tan Malak, 2000: 145-155).

Usaha perjuangan dalam mencapai pembebasan nasional Indonesia yang dilakukan Tan Malaka tidak hanya melalui perjuangan fisik saja akan tetapi dituangkan juga lewat gagasannya lebih kurang sekitar 27 buku, brosur dan juga ratusan artikel.Karya-karya Tan Malaka meliputi bidang kenegaraan, politik, ekonomi, sosial, budaya dan militer. Karya-karya Tan Malaka itu antara lain, Naar de Republik, Massa Aksi, Madilog, Semangat Muda dan lain-lain. Dari tulisan-tulisan itulah kita dapat mengenal dan menyelami gagasan-gagasan Tan Malaka yang selalu berlandaskan pada cara berfikir ilmiah, mengutamakan ke Indonesiaan, konsekuen, dan juga konsisten. Penerimaannya terhadap pemikiran Barat bukan berarti menyerahkan segala sesuatu pada hukum Barat tetapi lebih sebagai upaya untuk mempelajari nilai-nilai budaya Barat. Karena untuk dapat mengalahkan musuh tentulah harus di pahami kekuatan dan kekurangan dari musuh tersebut (Rambe, 2003: 90). 


\section{Usaha Perjuangan Pahlawan Datuk Ibrahim Tan Malaka pada Tahun 1946-1948}

Sejarah panjang perjuangan Bangsa Indonesia melawan penjajahan Belanda diakhiri dengan peristiwa Proklamasi Kemerdekaan Indonesia pada tanggal 17 Agustus 1945. Pasca Proklamasi kemerdekaan yang masih dilanda gejolak revolusi, para tokoh pergerakan terpecah dalam hal menggunakan metode untuk mencapai kemerdekaan. Dua opsi yang menjadi perdebatan yaitu perjuangan fisik dan perjuangan melalui diplomasi. Para pemimpin Indonesia mulai memperdebatkan jalan terbaik untuk mempertahankan kedaulatan Republik. Salah satu tokohnya adalah Tan Malaka. Prinsip Tan Malaka "Merdeka 100\%". Setelah proklamasi 17 Agustus 1945 Tan Malaka kemudian menjadi pimpinan gerakan yang bersemboyan "merdeka 100\%" (Zuhri, 2013: 406).

Tan Malaka menolak dan mengecam adanya perundingan Renville dan Linggarjati. Menurutnya perjanjian Linggarjati dan Renville keduanya telah mengurangi kemerdekaan Indonesia dalam urusan luar negeri, kemeliteran, keuangan, perekonomian, dan sangat menguntungkan Belanda (Malaka, 2008: 224). Selain itu menurutnya bahwa perjanjian tersebut melanggar arti proklamasi 17 Agustus 1945 dan terang-terangan membawa Indonesia kedalam bentuk penjajahan yang baru. Prinsip perjuangan atas dasar merdeka 100 porsen itu mendapatkan simpatik beberapa kelompok, terbukti pada Januari 1946 bersama 141 organisasi perjuangan Tan Malaka mendirikan Persatuan Perjuangan (PP) di Purwokerto sebagai organ baru dalam perjuangan mempertahankan kemerdekaan Indonesia, bahkan Jendral Sodirman pun memberikan sambutan dan mendukung program minimum perjuangan yang di hasilkan pada konggres ini. Kemudian selang 4 bulan beberapa pemimpin Persatuan Perjuangan pun ditangkap atas dasar tuduhan subversif dari kudeta 3 Juli 1946. Dengan ditangkapnya Tan Malaka dan beberapa pucuk pimpinannya, maka Persatuan Perjuangan sebagai organ dalam gagasan revolusioner pun dapat dikatakan mati (Triyana, 2010: 174).

Pada tanggal 7 November 1948 Tan Malaka, Chaerul Saleh, Sukarni dan Adam Malik. Mendirikan Partai Murba. Partai Murba mempunyai arti rakyat kecil yang berasal dari bahasa sangsekerta atau proletar dalam pengertian politik. Partai Murba adalah sebuah partai bagi rakyat, sehingga bersifat kerakyatan dan demokratis. Sebelum berdirinya partai Murba telah tersiar berita bahwa akan berdiri sebua partai yang menggabungkan tiga aliran besar dalam masyarakat yaitu Nasionalisme, Islamisme dan Sosialisme. Fanatik terhadap sala satu golongan atau aliran dengan merasa yang paling cakap memimpin tonggak revolusi tidak akan berhasil.

Tan Malaka perlu menegaskan bahwa perlunya kesatuan antara ketiga aliran tersebut untuk menjadikan revolusi di Indonesia berhasil, bukan tempatnya untuk salah satu aliran tadi merasa paling berhak dan mampu memimpin revolusi. beliau yang bertindak sebagai pelopor pendiri partai mendasarkan perjuangan pada aksi Murba dengan tujuan mempertahankan dan memperkokok kemerdekaan Indonesia (Hary Prabowo, 2002: 272).

Setelah satu bulan lebih terjadinya gejolak politik di Medium tanggal 18 September 1948. Tidak hanya Tan Malaka yang berpengaruh dalam pendiri partai Murba, ada pula tokoh-tokoh lain, Iwa Kusummasummantri, Achmad Soebardjo, Rustam Effendi dan Moh. Yamin. Partai Murba merupakan fusi dari beberapa partai yang tergabung dalam GRR antara lain: Partai Rakyat, Partai Rakyat Jelata dan Partai Buruh Merdeka, yang menyatukan tujuan menenteng Kapitalisme dan Imprealisme (Emalia I, Sukarni, 2013: 153).

Tan Malaka dianggap sebagai pemberontak berbahaya oleh pemerintahan perdana menteri Sjahril. Pertentangan gagasan sebuah kemerdekaan ini, memunculkan konflik begitu meruncing di dalam perjuangan-perjuangan kemerdekaan, konflik yang ada dalam negeri ini dimanfaatkan oleh kelompok internasional Amerika untuk dijadikan ruang mengambil kembali dominasi terhadap bangsa Indonesia. Pertentangan konsep kemerdekaan semakin memanas ketika pemerintahan Indonesia menyetujui perjanjian linggarjati, Renville dan berujung ke KMB yang menggadaikan kembali kemerdekaan bangsa Indonesia terhadap kolonialisme. Keadaan itulah yang membuat Tan 
Malaka bersama Persatuan Perjuangan dan Partai Murba menjadi kekuatan oposisi yang menentang imprialisme dan arah politik pemerintah Indonesia yang di anggap menggadai kemerdekaan dan kedaula bangsa Indonesia. Sejak saat itulah Tan Malaka diburuh oleh tentara Negara yang dia belah mati-matian selama tiga puluh tahun terakhir, sampai akhirnya terbunuh oleh tentara nasional Indonesia di Kediri Jawa Timur pada tanggal 19 Febuari 1949 dan jenazahnya tidak di ketahui sampai sekarang. Namun dalam Penelitiannya Harry A. Poeze mengatakan kuburan Tan Malaka ada di Kediri Jawa Timur. Di mana Tan Malaka di eksekusi dipinggir sungai, diikat dekat bukit kemudian mayatnya dihanyutkan di Kali Brantas (Harry A, Poeze, 2010: 10).

\section{Kesimpulan}

Berdasarkan hasil penelitian ini menunjukan bahwa 1) kondisi Nusantara pada masa pergerakan nasional sudah mengalami perbaikan walaupun masih ada diskriminasi di beberapa aspek, misalnya dalam aspek pendidikan munculnya beberapa tokoh yang mempelopori pergerakan nasional Indonesia di antaranya Dr. Soetomo, Ki Hajar Dewantara, Wahid hasym, Samanhudi, Abdul Muis dan satu tokoh yang dilupakan dalam kanca sejarah Indonesia yaitu Tan Malaka. Lahirnya golongan terpelajar ini yang mampu membuka kesadaran bahwa ilmu pengetahuan merupakan bekal untuk menghadapi bangsa Barat menuju kemerdekaan, sementara dalam bidang politik, lahirnya beberapa organisasi di antaranya Budi Utomo, Sarekat Islam, PKI dan lain sebagainya membawa dampak positif bagi rakyat Indonesia. Di bidang ekonomi terjadi kepentingan penjajah lebih diutamakan dari pada kepentingan rakyat jajahan. Kepentingan tersebut menyebabkan kondisi rakyat jajahan yang terbelakang, akibat pelaksanaan eksploitasi dan diskriminasi pemerintah kolonial Belanda.kondisi sosial bangsa Indonesia pada awal abad ke-20 juga menghadapi praktek diskriminasi dari kolonial Belanda. Diskriminasi itu berdasarkan ras, golongan dalam masyarakat dan suku bangsa. 2) usaha perjuangan Pahlawan Datuk Ibrahim Tan Malaka dalam mencapai pembebasan Nasional Indonesia tidak bisa dipisakan dari latar belakang kehidupan sosialnya, semasa kecil Tan Malaka bersekolah di Bukittinggi kemudian pergi ke Belanda untuk melanjutkan pendidikannya. Semasa Tan Malaka sekolah di Belanda, situasi Eropa sedang dalam masa pergolakan, pengalaman dan ilmu lebih banyak diperoleh melalui berita-berita dan buku-buku yang dibacanya. Dalam usaha perjuangan Tan Malaka, perlunya persatuan harus dilakukan segenap rakyat untuk memperoleh kemerdekaannya. Keadaan rakyat Indonesia terhisap oleh kolonialisme Belanda, sehingga Tan Malaka mengkonsepkan perjuangan harus dilakukan melalui aksi massa yang teratur, terdidik dan terpimpin, dimana rakyat proletar harus mengkonsolidasikan kekuatan dirinya melawan penghalang kemerdekaan 100\%. Namun hal yang perlu dilakukan oleh rakyat proletar sebelum melakukan aksi massa, dimana aksi massa yang di lakukan harus memiliki kesatuan tekad, jiwa yang revolusioner dan pemimpin yang revolusioner yang mampu membawa dan memimpin rakyat proletar menuju kemerdekaan dan kedaulatan. 3) usaha perjuangan pahlawan Datuk Ibrahim Tan Malaka dalam mencapai pembebasan nasional Indonesia tahun 1919-1949 di mulai pada tahun 1919 dan mencapai puncak karirnya tahun 1921-1922 merupakan permulaan nyata bagi karir politik Tan Malaka mendirikan sekolah rakyat di Semarang. menjadi ketua PKI menggantikan Samaun, mendirikan Partai Republik Indonesia PARI di Bangkok, menggagas terbentuknya organisasi pesatuan perjungan, dan pada tanggal 7 November 1948 Tan Malaka mendirikan partai yang bersifat revolusioner untuk mempertahankan kemerdekaan Indonesia yang bernama partai Murba. Dalam anggaran dasar partai Murba bertujuan untuk mempertahankan dan memperkokoh tegaknya kemerdekaan $100 \%$ bagi republik dan rakyat, sesuai dengan dasar dan tujuan proklamasi kemerdekaan Indonesia, menuju masyarakat adil dan makmur menurut kepribadian bangsa Indonesia adalah masyarakat Sosialis.

\section{Daftar Pustaka}

Alfian. (1986). Transformasi Sosial Budaya dalam Pembangunan Sosial. Jakarta: UI Press. 
Adi Susilo, Taufik. 2008. Tan Malaka Biografi Singkat 1897-1949. Yogyakarta: Garasi.

.. (1992). Pemikiran dan Perubahan Politik Indonesia. Jakarta: Gramedia. Anshory ch.

Djojoprajitno, Sudijono. 2010. Tan Malaka: Pemberontakan PKI 1926, Menolak Blankuisme. Jakarta: LPPM Tan Malaka.

Gottcshalk, Louis, A.N Nugroho Notosusanto. 1985. Mengerti Sejarah. Jakarta: UI Press.

Hugiono, dkk. 1992. Pengantar Ilmu Sejarah. Jakarta: Rineka Cipta.

Kartodirdjo, Salma. (1999). Pendekatan Ilmu Sosial dalam Metodologi Sejarah. Jakarta: Gramadia Pustaka Utama.

Malaka, Tan. 2007. Sarekat Islam (SI) semarang dan Onderwijs. Semarang: Yayasan Masa.

. 2000. Dari Penjara Ke Penjara Bagian III. Jakarta: Teplok Perss.

. 1926. Semangat Muda. Tokyo: Sega Arsy.

. 1943. Madilog. Yogyakarta: Narasi.

Sumardi, Dkk. (2017). Jurnal Historika. (Vol. 1 No 2252-4673), Jakarta: ISSN. Tirtoprodjo.

Poeze, Harry A. 2008. Tan Malaka Gerakan Kiri dan Revolusi Indonesia Jilid 1. Jakarta: Yayasan Obor Indonesi.

. 2009. Tan Malaka Gerakan Kiri dan Revolusi Indonesia Jilid I1. Jakarta: Yayasan Obor Indonesi. 